\title{
PIK3C2G wt Allele
}

National Cancer Institute

\section{Source}

National Cancer Institute. PIK3C2G wt Allele. NCI Thesaurus. Code C102946.

Human PIK3C2G wild-type allele is located in the vicinity of $12 \mathrm{p} 12$ and is approximately $401 \mathrm{~kb}$ in length. This allele, which encodes phosphatidylinositol 4-phosphate 3-kinase C2 domain-containing subunit gamma protein, plays a role in both the phosphorylation of phospholipids and the modulation of second messenger signaling. 